\title{
Emma J. Cayley, Drawing Conclusions: the Poetics of Closure in Alain Chartier's Verse
}

\section{Maria Colombo Timelli}

\section{(2) OpenEdition}

1 Journals

\section{Édition électronique}

URL : https://journals.openedition.org/studifrancesi/37257

DOI : 10.4000/studifrancesi.37257

ISSN : 2421-5856

Éditeur

Rosenberg \& Sellier

\section{Édition imprimée}

Date de publication : 15 décembre 2004

Pagination : 583

ISSN : 0039-2944

\section{Référence électronique}

Maria Colombo Timelli, « Emma J. Cayley, Drawing Conclusions: the Poetics of Closure in Alain Chartier's Verse ", Studi Francesi [En ligne], 144 (XLVIII | III) | 2004, mis en ligne le 30 novembre 2015, consulté le 08 mai 2021. URL : http://journals.openedition.org/studifrancesi/37257 ; DOI : https://doi.org/ 10.4000/studifrancesi.37257

Ce document a été généré automatiquement le 8 mai 2021.

\section{(c)}

Studi Francesi è distribuita con Licenza Creative Commons Attribuzione - Non commerciale - Non opere derivate 4.0 Internazionale. 


\title{
Emma J. Cayley, Drawing Conclusions: the Poetics of Closure in Alain Chartier's
} Verse

\author{
Maria Colombo Timelli
}

\section{RÉFÉRENCE}

EMMA J. CAYLeY, Drawing Conclusions: the Poetics of Closure in Alain Chartier's Verse, «Fifteenth-Century Studies», 28, 2002, pp. 51-64.

1 On examine ici la poétique de la 'clôture' dans un certain nombre de débats d'Alain Chartier: Le Debat du Herault, du Vassault et du Villain, Le Debat de Reveille Matin, La Belle Dame sans mercy, L'excusacion des Dames, Le Debat des Deux Fortunés d'Amours, Le Livre des Quatre Dames, auxquels s'ajute Le Lay de Paix. À l'intérieur d'un cadre formel et métrique rigidement structuré, A. Chartier introduit des éléments d'instabilité, et cela tant sur le plan du jugement à exprimer, que pour le lexique utilisé. Malgré la conclusion apparente, ses poèmes demeurent par consequent irrésolus, et leur clôture n'en est finalement pas une. 